\title{
Physiological Adaptation of the Amphibious Rocks Crab Grapsus tenuicrustatus from the Red Sea
}

\author{
A. A. EshKY \\ Faculty of Marine Science, King Abdulaziz University, \\ Jeddah, Saudi Arabia
}

\begin{abstract}
The rate of weight specific oxygen consumption in the Red Sea supra littoral crab Grapsus tenuicrustatus was examined under aerial and aquatic conditions. This indicates that the smallest crabs had the highest weight specific oxygen consumption, and the rate of aquatic respiration was lower than that in air. The effect of temperature on the rate of oxygen consumption and heart beat was also investigated. The $\mathrm{Q}_{10}$ values for both oxygen consumption and heart rate were often $<2$ and were relatively constant over a wide range of temperature. This suggests the G. tenuicrustatus is well adapted over a wide range of temperature. Gill area and brachial volume were also examined in a size range of crabs. The species had fewer gills and less gill area than aquatic crabs. These observations enable further understanding of adaptations which allow Grapsus tenuicrustatus to occupy the high supra littoral zone.
\end{abstract}

\section{Introduction}

The family Grapsidae including the genus Grapsus comprises crabs that can be commonly found occupying fringe area of the littoral zone, under stones, in wreckage, and in crevices (Barnard, 1950; Banerjee, 1960; Forest and Guinot, 1961; Crosnier, 1965; and Eshky, 1980). After the construction of the coastal highway (Al-Cornich in 1980), in the Red Sea area around Jeddah city, the lava rocks and boulders along the highway provide the grapsid crab Grapsus tenuicrustatus and other associated species with a good protection not only from predators but also from environmental extremes. Therefore Grapsus tenuicrustatus has now become the most conspicuous member of the new environment. During night hours most of its time is spent in crevices under the rocks surface close to the water surface between rocks. It emerges to forage during daylight hours, scavenging amongst rocks and feeding on encrusting organisms exposed on the rocks faces by falling tide. Grapsus tenuicrustatus is primarily an air breather and can withstand short periods of immersion (Eshky, 1992a\&b). Respiratory studies on brachyuran crabs have largely concentrated on extremes of adaptation, investigating either terrestrial species (review by McMahon and Burggren, 1988) or the aquatic species not showing activity in the air (Burnett, 1988; DeFur, 1988; and McMahmon, 1988). Both 
investigations were often combined with a study of ventilatory and cardiac activity. Comparatively little information is available for supralittoral amphibious species but includes the grapsid species Leptograpsus vaiegatus (Greenaway et al., 1992; and Foster et al., 1989). In addition, aerial and aquatic respiration in semi-terrestrial crab Ocypode saratan has received detailed study (Eshky, 1985; and Al-Wassia et al., 1988).

Earlier studies of oxygen consumption of Ocypode spp. compared the oxygen consumption of seven species of crab in relation to habitat (Ayers, 1938). Only one of these Ocypode quadrata was semi-terrestrial, and this had the highest rate of oxygen consumption. In similar comparative studies, but using isolated gills tissue, Ocypode quadrata again demonstrated the highest rate of oxygen consumption (Vernberg, 1956). Veerman (1974) showed that in Ocypode platytarsis oxygen consumption rates in air are lower than in water. Innes and Taylor (1986) showed the rates of oxygen consumption (quiescent and active) in Ocypode quadrata were remarkably similar to those of other tropical air breathing crabs. Wolcott (1978) also provided some information on quiescent rates of oxygen consumption of this species as a component of a study on feeding energetics.

Renewed interest in the study of gill areas of brachyuran crabs is seen in the shore crab Carcinus mediterraneus (Lucu and Pavicic, 1995). In addition, gill areas in the semiterrestrial crab Ocypode saratan has received a detailed study (Eshky, 1985). In earlier studies, Hawkins and Jones (1982) have investigated gill area in two mud crabs, Helice crassa and Macrophthalamus hertipes, both of which are littoral but the former extends into semi-terrestrial condition and the latter remains immersed. In general amphibious crabs from terrestrial and semi-terrestrial habitat have fewer gills, reduced gill surface area and more efficient branchial ventilation when in air relative to aquatic species (Eshky, 1985 and 1992a\&b; Eshky et al., 1990; Hawkins and Jones, 1982; Gray, 1957; Alexander and Ewer, 1969; Greenway and Taylor, 1976; and Diaz and Rodrigues, 1977).

The present study presents the results of an investigation into the effect of temperature on aerial oxygen consumption and heart rate in the grapsid crabs Grapsus tenuicrustatus. Some information on the aquatic rate of oxygen consumption and gill area is also presented.

\section{Materials and Methods}

For laboratory investigation the crabs were obtained from different locations along the coastline by trapping buckets placed between the rocks at depth of $20 \mathrm{~cm}$ below the rock surface. They are usually baited with small dead fish and were transported to Obhor Marine Station of Faculty of Marine Science, King Abdulaziz University, Jeddah, where they were held in an indoor aquarium at $25^{\circ} \mathrm{C}$ for 7 days before the commencement of experiments.

\section{Oxygen Consumption}

Rates of oxygen consumption in air and water were determined using a constant pressure aerial respirometer of the type described by Davies (1966). Six of these respirometers were employed simultaneously. They were mounted in a water bath maintained at 
the required temperature and shielded with opaque plastic sheeting to minimize the disturbance caused either by the observer or by adjacent crabs.

Experimentation indicated that disturbance caused by handling the crabs, when placing them in the respirometers, resulted in elevated rates of oxygen consumption $\left(\mathrm{VO}_{2}\right)$ that normally took 4-6 hours to decline to a constant rate characteristics of unstressed and inactive crabs. Therefore, crabs were allowed to acclimate to the experimental condition for 6 hours before measurements of oxygen consumption were taken. Aquatic oxygen consumption was investigated at $25^{\circ} \mathrm{C}$ using closed system respirometer described by Eshky and Ba-Akdhah (1992). The lid of the respirometer was fitted with two taps, which, when open, allowed aerated seawater to be continuously circulated through the vessel. The crabs were placed in the respirometer and left undisturbed for a period of at least six hours. The taps fitted to the respirometer were then closed and the rate of depletion of the oxygen was monitored using a Radiometer oxygen electrode (5046) inserted through the respirometer lid and connected to an oxygen meter (Starthkelvin instruments). In order to ensure that the rate of oxygen consumption was unaffected by hypoxic stress, the oxygen content of the water was never allowed to fall below approximately $80 \%$ saturation, during recording.

The rates of aerial and aquatic oxygen consumption at different temperatures were plotted as a function of wet body weight on a double logarithmic scale. Regression lines were fitted to these data using the method of least squares and elevations compared using covariance analysis. Using these regression equations, $\mathrm{Q}_{10}$ values were determined for crabs of different sizes.

\section{Heart Rate}

Recordings of heart rate were obtained using the impedance technique (Hoggarth and Trueman, 1967). Silver wire electrodes were inserted into small holes drilled in the carapace on either side of the heart and secured with cyanoacrylate adhesive. The electrode wires were connected to impedance couplers (Starthkelvin Instruments, Glasgow) and impedance changes were amplified and recorded using Washington MD2 Oscillograph (Searle Bioscience, Sheerness).

Recordings of heart rates were made from adopted crabs at the following temperatures: $15,20,25,30$ and $35^{\circ} \mathrm{C}$. Data analysis was similar to that described for oxygen consumption.

\section{Gill Area}

For determination of gill area and the number of gill lamellae, the method followed was similar to that used by Gray (1957). Live crabs were wiped with tissue paper to remove excess water and then weighed. Carapace width and sex were also recorded. The crabs were then sacrificed by killing them at low temperature (fridge) following which the gills were removed from the right branchial chamber in each case and placed singly in labeled petri dishes containing sea water. The length of each was measured using digital precision caliper. Following this, the number of gill lamellae per millimeter was de- 
termined using the ocular micrometer of a dissecting microscope. Several regions of the gill were examined and knowing the total length of the gill and the number of gill lamellae per unit length, the total number was then determined by multiplication. To account for the different size of the gill lamellae, both along the length of the gill and either side of the midline, the gill was examined distally, proximately and at the midpoint and one pair of opposed lamellae was examined from each of these regions. In this way the overestimation of gill area implicit in just using the lamellae at the middle of the gill (Gray, 1957; and Veerannan, 1974) are avoided. The isolated lamellae were mounted in sea water on a slide and using a dissecting microscope with camera lucida (Wild), their outlines drawn. Lamella area was determined using AutoCAD program on a PC computer.

The total gill area (mm) for each individual (A) was calculated from the formula:

$$
A=4(a n+a n+a n+\ldots .+a n)
$$

Where $n$ is the number of lamellae along each side of the filament and $a$ is the surface area of average-sized lamella (two sides). The gills from the left branchial chamber were assumed to have the same area as those from the right. The volume of the branchial chamber was measured for Grapsus tenuicrustatus employing two methods. Initially, the method of Diaz and Rodrigues (1977) was followed in which specimens were killed by immersion in $10 \%$ formalin and weighed after the removal of surplus fluid from the body and gill chamber. The pereiopods were removed prior to weighing, this removing variability caused by specimens that had autotomised limbs. Melted paraffin wax was syringed into the Milne-Edwards opening the gill chamber was filled. This was checked by cutting a small "window" in the roof of the gill chamber through which any necessary topping-up of the wax could be achieved. The resulting cast perfectly represented the shape of the chamber and its volume was determined from the weight of the cast and density of the wax. In each crab used, both branchial chambers were cast with wax and the mean branchial volume was taken. A total of 20 crabs were used. An alternative to paraffin wax, the water method of Eshky (1985) was employed in which twenty crabs were killed at low temperature (fridge), surplus water was removed from the body surface and branchial chambers and the crabs were weighed. All inhalant and exhalent openings were closed using cyanoacrylate glue and a small hole was drilled on the dorsal side of each branchial chamber. Using a scaled burette, each branchial chamber was carefully filled with water and the volume noted from the burette. This appeared to be a more satisfactory technique, reducing variability in data compared to the wax paraffin method (Diaz and Rodrigues, 1977).

\section{Results}

\section{Heart Rate}

The relationship between heart rate and body weight from quiescent crabs at different temperatures is shown in Fig. (1). The equations for the regression lines fitted to these data are given in Table (1). 


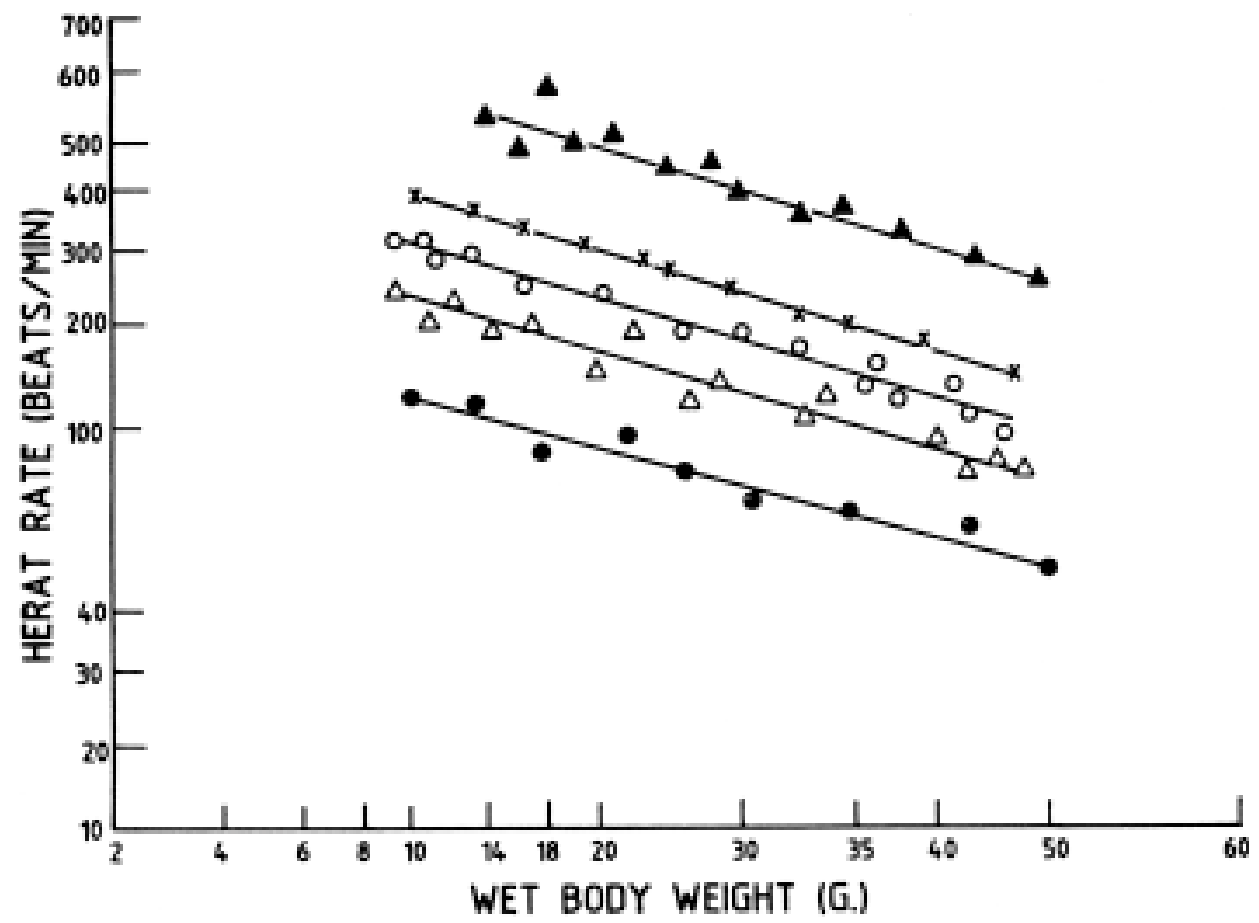

FIG. 1. Relationship between heart rate and wet body weight of Grapsus tenuicrustatus at different temperatures $\left(15^{\circ} \mathrm{C}-\mathrm{O}, 20^{\circ} \mathrm{C}-\Delta, 25^{\circ} \mathrm{C}-\mathrm{O}, 30^{\circ} \mathrm{C}-\mathrm{x}, 35^{\circ} \mathrm{C}-\Delta\right)$.

TABLE 1. Regression equations for heart rate (beats/min) (Y) against wet weight $(\mathrm{g})(\mathrm{X})$.

\begin{tabular}{|c|l|c|c|}
\hline Heart rate (beats / min) & Regression equation & $\mathrm{r}$ & $\mathrm{n}$ \\
\hline Temperature $^{\circ} \mathrm{C}$ & $\log _{10} \mathrm{y}=\log _{10} \mathrm{a}-\mathrm{b} \log _{10} \mathrm{x}$ & & \\
\hline 15 & $\log \mathrm{y}=2.66-0.51 \log \mathrm{x}$ & 0.99 & 9 \\
\hline 20 & $\log \mathrm{y}=3.38-0.73 \log \mathrm{x}$ & 0.99 & 15 \\
\hline 25 & $\log \mathrm{y}=3.41-0.81 \log \mathrm{x}$ & 0.93 & 17 \\
\hline 30 & $\log \mathrm{y}=3.42-9.75 \log \mathrm{x}$ & 0.97 & 13 \\
\hline 35 & $\log \mathrm{y}=3.58-0.64 \log \mathrm{x}$ & 0.95 & 14 \\
\hline
\end{tabular}

In each case the regression line is a highly significant fit $(\mathrm{p}<0.001)$.

Covariance analysis (Table 2) showed that the slopes (b) of the regression lines fitted to the $15^{\circ} \mathrm{C}$ and $20^{\circ} \mathrm{C}$ data were only just below the significant level $(0.1>\mathrm{p}>0.05)$ from each other, and from the data for $25^{\circ} \mathrm{C}, 30^{\circ} \mathrm{C}$ and $35^{\circ} \mathrm{C}$. The slopes of the regression lines fitted to the $25-35^{\circ} \mathrm{C}$ data were not significantly different from each other. 
There were however, significant differences in the elevation (a) of the regression equations of the lines fitted to these data, Table (2). A corresponding pronounced increase in the heart rate between $15^{\circ} \mathrm{C}$ and $20^{\circ} \mathrm{C}$ and also between $30^{\circ} \mathrm{C}$ and $35^{\circ} \mathrm{C}$ is reflected in the high $\mathrm{Q}_{10}$ values shown in Table (3), otherwise the $\mathrm{Q}_{10}$ values are very consistent over the rest of the temperature ranges studied.

TABLE 2. Covariance comparison of heart rate.

\begin{tabular}{|c|c|c|}
\hline Compared group & Label (a) & Label (b) \\
\hline $15-20^{\circ} \mathrm{C}$ & $\mathrm{S}(\mathrm{P}<0.001)$ & $\mathrm{NS}(0.1>\mathrm{P}>0.05)$ \\
\hline $20-25^{\circ} \mathrm{C}$ & $\mathrm{S}(\mathrm{P}<0.025)$ & $\mathrm{NS}$ \\
\hline $25-30^{\circ} \mathrm{C}$ & $\mathrm{S}(\mathrm{P}<0.025)$ & $\mathrm{NS}$ \\
\hline $30-35^{\circ} \mathrm{C}$ & $\mathrm{S}(\mathrm{P}<0.001)$ & $\mathrm{NS}$ \\
\hline
\end{tabular}

( $\mathrm{S}=$ significant NS $=$ not significant $)$

TABLE 3. $\mathrm{Q}_{10}$ values for heart rate of Grapsus tenuicrastatus in air.

\begin{tabular}{|c|c|c|c|c|c|c|c|}
\hline \multirow{2}{*}{$\begin{array}{c}\text { Weight } \\
(\mathrm{g})\end{array}$} & \multicolumn{4}{|c|}{$\mathrm{Q}_{10}$ over $5^{\circ} \mathrm{C}$ intervals } & \multicolumn{3}{c|}{$\mathrm{Q}_{10}$ over $10^{\circ} \mathrm{C}$ intervals } \\
\cline { 2 - 8 } & $15-20^{\circ} \mathrm{C}$ & $20-25^{\circ} \mathrm{C}$ & $25-30^{\circ} \mathrm{C}$ & $30-35^{\circ} \mathrm{C}$ & $15-25^{\circ} \mathrm{C}$ & $20-30^{\circ} \mathrm{C}$ & $25-35^{\circ} \mathrm{C}$ \\
\hline 8 & 3.94 & 1.78 & 1.55 & 2.55 & 2.53 & 1.70 & 1.92 \\
\hline 10 & 3.69 & 1.63 & 1.52 & 2.62 & 2.66 & 1.65 & 1.95 \\
\hline 20 & 3.18 & 1.87 & 1.54 & 2.71 & 2.70 & 1.66 & 2.01 \\
\hline 30 & 3.71 & 2.01 & 1.56 & 2.61 & 2.51 & 1.60 & 2.10 \\
\hline 40 & 2.75 & 2.44 & 1.45 & 2.97 & 2.17 & 1.71 & 2.21 \\
\hline 50 & 2.66 & 1.87 & 1.49 & 3.18 & 2.03 & 1.61 & 2.48 \\
\hline
\end{tabular}

\section{Oxygen Consumption in Air}

Rates of aerial oxygen consumption $\mathrm{MO}_{2}$ data (Fig. 2) in the present study indicate that as temperature increases oxygen consumption increases at the weight range of crabs tested. The lines of the regression equations fitted to the data are presented in Table (4). Covariance analysis of this data showed that there was no significant difference in the slopes (b) of the regression line fitted to these data, but the differences in their elevations were significant (a) (Table 5). The similarity in the slopes of these regression lines indicates that the effect of temperature was constant over a particular size of crabs tested. $\mathrm{Q}_{10}$ values, derived from the $\mathrm{MO}_{2}$ data were not entirely constant over the range of temperature employed. Notable differences were seen when the $\mathrm{MO}_{2}$ data for $15-20^{\circ} \mathrm{C}$ and $25-35^{\circ} \mathrm{C}$ are compared. Here $\mathrm{Q}_{10}$ values for $15-20^{\circ} \mathrm{C}$ range from 2.9 for $8 \mathrm{~g}$ crabs to 1.94 for $50 \mathrm{~g}$ crabs. $\mathrm{Q}_{10}$ values for $30-35^{\circ} \mathrm{C}$ range from 187 for $8 \mathrm{~g}$ crabs to 2.79 for $50 \mathrm{~g}$ crab, otherwise values are between 1.56 and 1.75 (Table 6). 


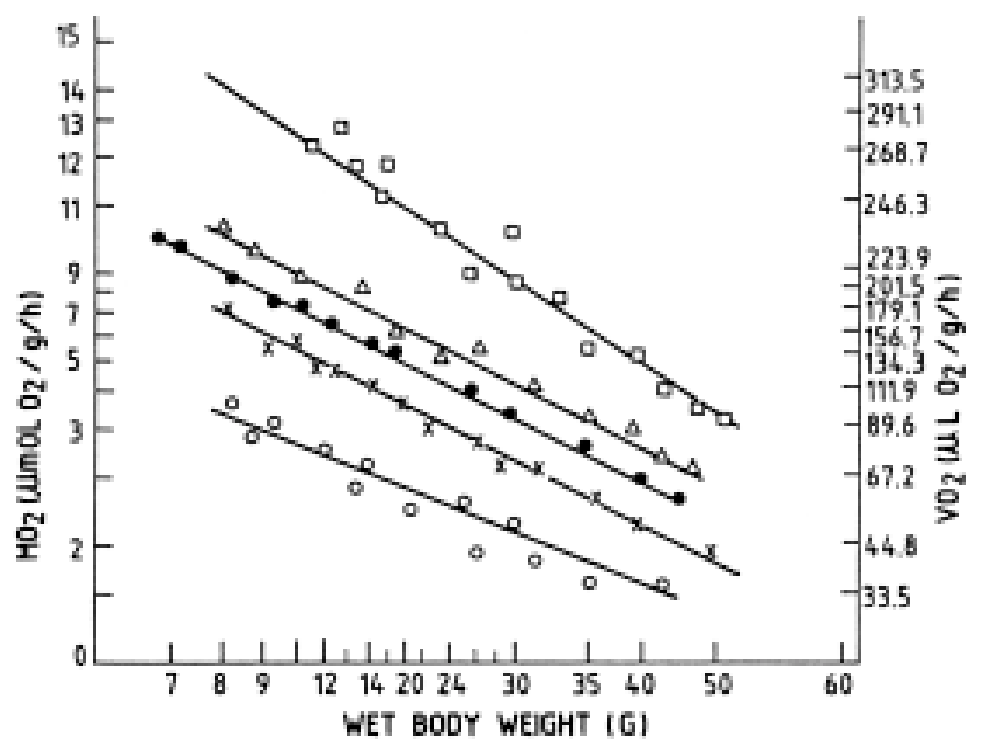

FIG. 2. Relationship between aerial weight specific rates of oxygen consumption and wet body weight of Grapsus tenuicrustatus at different temperatures $\left(15^{\circ} \mathrm{C}-\mathrm{O}, 20^{\circ} \mathrm{C}-\mathrm{x}, 25^{\circ} \mathrm{C}-\mathrm{O}, 30^{\circ} \mathrm{C}-\Delta, 35^{\circ} \mathrm{C}-\square\right)$.

TABLE 4. Regression equations $\mathrm{MO}_{2}\left(\mu \mathrm{mol} . \mathrm{O}_{2} / \mathrm{g} / \mathrm{h}\right) \mathrm{Y}$ against wet weight $(\mathrm{g})(\mathrm{X})$.

\begin{tabular}{|c|c|c|c|}
\hline Aerial respiration & Regression equation & $\mathrm{r}$ & $\mathrm{n}$ \\
\hline Temperature ${ }^{\circ} \mathrm{C}$ & $\log _{10} y=\log _{10} a-b \log _{10} x$ & & \\
\hline 15 & $\log y=1.23-0.62 \log x$ & 0.96 & 13 \\
\hline 20 & $\log y=1.52-0.68 \log x$ & 0.98 & 13 \\
\hline 25 & $\log y=1.65-0.70 \log x$ & 0.97 & 13 \\
\hline 30 & $\log y=1.720-0.69 \log x$ & 0.92 & 12 \\
\hline 35 & $\log y=2.2-0.69 \log x$ & 0.91 & 15 \\
\hline \multicolumn{4}{|l|}{ Aquatic respiration } \\
\hline 25 & $\log y=1.17-0.58 \log y$ & 0.92 & 14 \\
\hline
\end{tabular}

Table 5. Covariance comparison of aerial \& aquatic oxygen consumption.

\begin{tabular}{|c|c|c|}
\hline Compared group & Label (a) & Label (b) \\
\hline $15-20^{\circ} \mathrm{C}$ & $\mathrm{S}(\mathrm{P}<0.001)$ & $\mathrm{NS}$ \\
\hline $20-25^{\circ} \mathrm{C}$ & $\mathrm{S}(\mathrm{P}<0.025)$ & $\mathrm{NS}$ \\
\hline $25-30^{\circ} \mathrm{C}$ & $\mathrm{S}(\mathrm{P}<0.01)$ & $\mathrm{NS}$ \\
\hline $30-35^{\circ} \mathrm{C}$ & $\mathrm{S}(\mathrm{P}<0.001)$ & $\mathrm{NS}$ \\
\hline Aerial-quatic & $\mathrm{S}(\mathrm{P}<0.001)$ & $\mathrm{NS}$ \\
\hline
\end{tabular}


TABLE 6. $\mathrm{Q}_{10}$ values for oxygen consumption of Grapsus tenuicrustatus in air.

\begin{tabular}{|c|c|c|c|c|c|c|c|}
\hline \multirow{2}{*}{$\begin{array}{c}\text { Weight } \\
(\mathrm{g})\end{array}$} & \multicolumn{4}{|c|}{$\mathrm{Q}_{10}$ over $5^{\circ} \mathrm{C}$ intervals } & \multicolumn{3}{c|}{$\mathrm{Q}_{10}$ over $10^{\circ} \mathrm{C}$ intervals } \\
\cline { 2 - 8 } & $15-20^{\circ} \mathrm{C}$ & $20-25^{\circ} \mathrm{C}$ & $25-30^{\circ} \mathrm{C}$ & $30-35^{\circ} \mathrm{C}$ & $15-25^{\circ} \mathrm{C}$ & $20-30^{\circ} \mathrm{C}$ & $25-35^{\circ} \mathrm{C}$ \\
\hline 8 & $2-9$ & 1.72 & 1.72 & 1.87 & 2.17 & 1.29 & 1.48 \\
\hline 10 & $2-5$ & 1.74 & 1.75 & 1.71 & 1.84 & 1.52 & 1.56 \\
\hline 20 & $2-6$ & 1.72 & 1.65 & 2.16 & 1.92 & 1.66 & 1.79 \\
\hline 30 & $2-2$ & 1.75 & 1.56 & 2.69 & 2.04 & 1.62 & 2.11 \\
\hline 40 & $2-3$ & 1.71 & 1.69 & 2.68 & 1.82 & 1.61 & 2.13 \\
\hline 50 & $1-94$ & 1.7 & 1.56 & 2.79 & 1.79 & 1.61 & 1.91 \\
\hline
\end{tabular}

\section{Oxygen Consumption in Water}

The rate of aquatic oxygen consumption was investigated at only one temperature, $25^{\circ} \mathrm{C}$, since it was close to the average environmental temperature. The data obtained is shown in Fig. (3). Covariance analysis indicates no significant differences between the slopes of the regression lines between aerial and aquatic respiration at the same temperature, but the difference in their elevation is significant (Table 5).

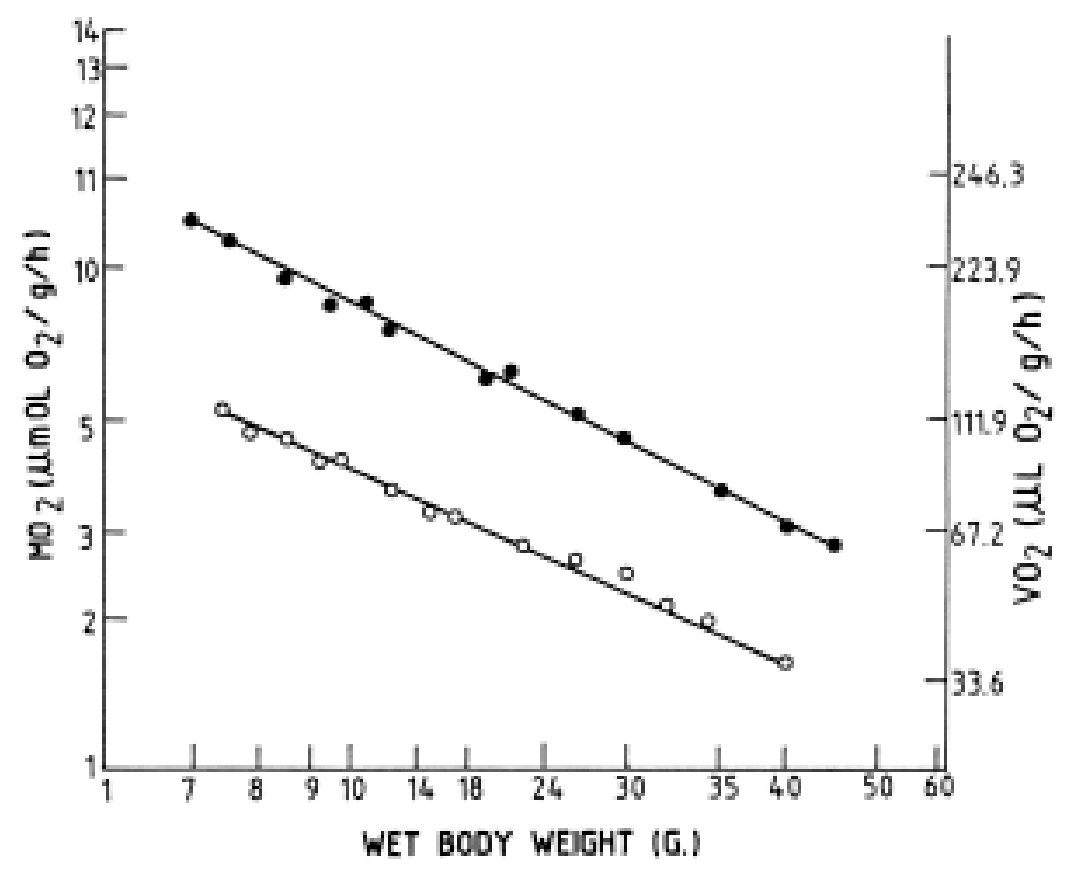

FIG. 3. Relationship between weight specific rates of oxygen consumption and wet body weight of Grapsus tenuicrustatus in air $(\mathrm{O})$ and in water $(\mathrm{O})$ at $25^{\circ} \mathrm{C}$. 


\section{Gill Area}

Small Grapsus tenuicrustatus have a greater number of gill lamellae per gram body weight than larger crabs, and a more pronounced rate of decline in number with increasing body weight (Fig. 4). Eshky (1985) reported a similar relationship between lamellae number and body weight for the ghost crab Ocyode saratan described by the equation $\left(\log _{10} \mathrm{y}=3.36-0.94 \log \mathrm{x}\right)$. In the present work on Grapsus tenuicrustatus the equivalent equation is $\left(\log _{10} \mathrm{y}=3.55-0.94 \log _{\mathrm{x}} \mathrm{r}=0.94\right)$ where $\mathrm{x}=$ wet body weight $(\mathrm{g})$ and $\mathrm{y}$ = gill area per gram body weight. Also regression line (Fig. 4) shows that gill area per gram wet body weight declines with increasing body weight $\left(\log _{10} \mathrm{y}=3.2-04 \log \mathrm{x}\right.$ $r=0.97$ ) where $x=$ wet body weight and $y=$ gill area per gram body weight. For example, a crab of 12.5 gram weight had a gill area of $603 \mathrm{~mm}^{2} \mathrm{~g}^{-1}$ and 418 individual lamellae $\mathrm{g}^{-1}$ whereas a crab of 52 gram weight had gill area of $250 \mathrm{~mm}^{2} \mathrm{~g}^{-1}$ and 68 individual lamellae $\mathrm{g}^{-1}$.

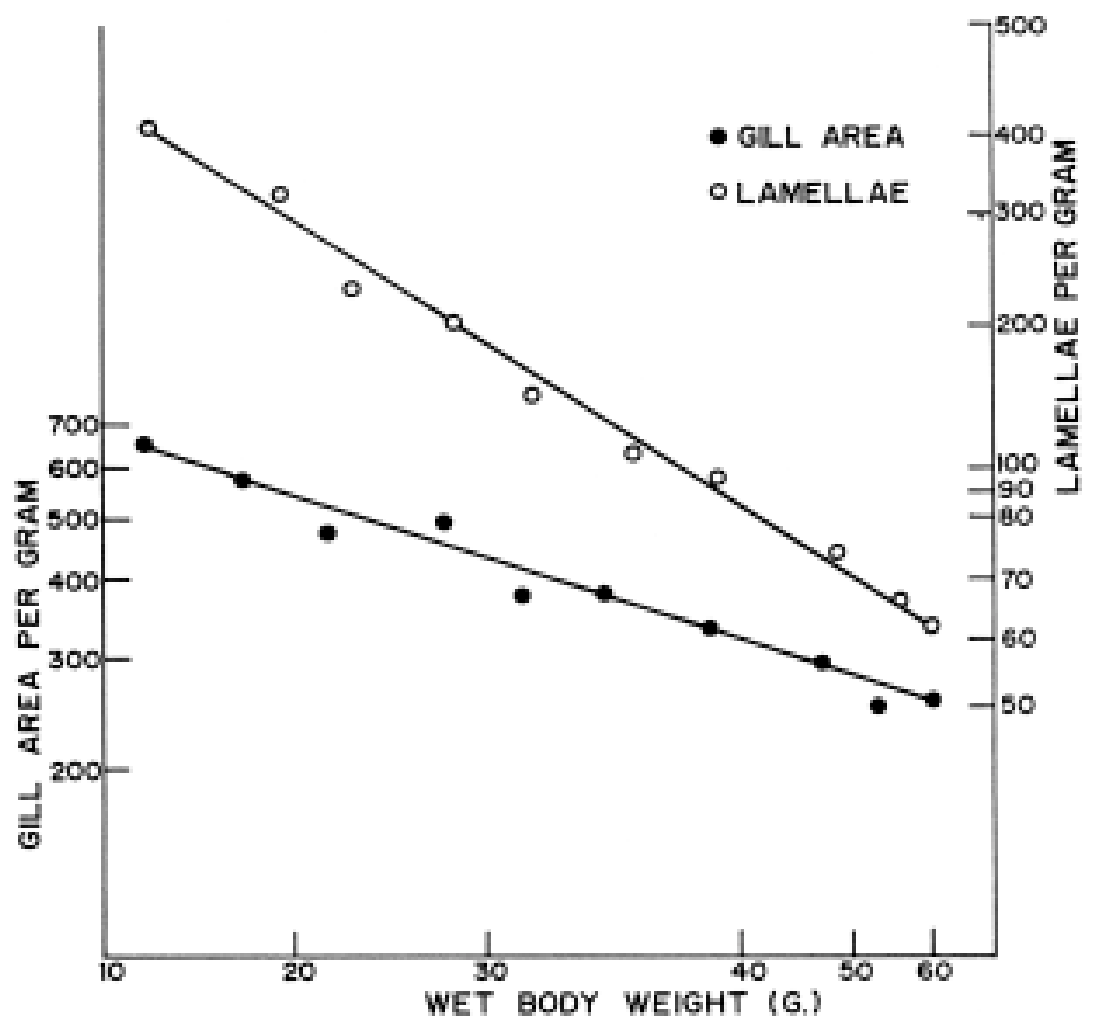

FIG. 4. Total gill area (O) and total number of gill lamellae $(\mathrm{O})$ of Grapsus tenuicrustatus as a function of wet body weight $(\mathrm{g})$.

\section{Branchial Chamber Volume}

The relationships between the crab's body weight and branchial chamber volume, employing both the wax and water methods, are shown in Fig. (5). The regression lines 
fitted to the data are given in Table (7). The covariance analysis of the regression lines fitted to the data show no significant difference, either between the slopes or the elevations of the two regression lines. The relative higher value of the correlation coefficient of the water method compared to the wax method, is most probably because the water penetrates all the branchial spaces including the interlamellar spaces, whereas the wax does not penetrate so well.

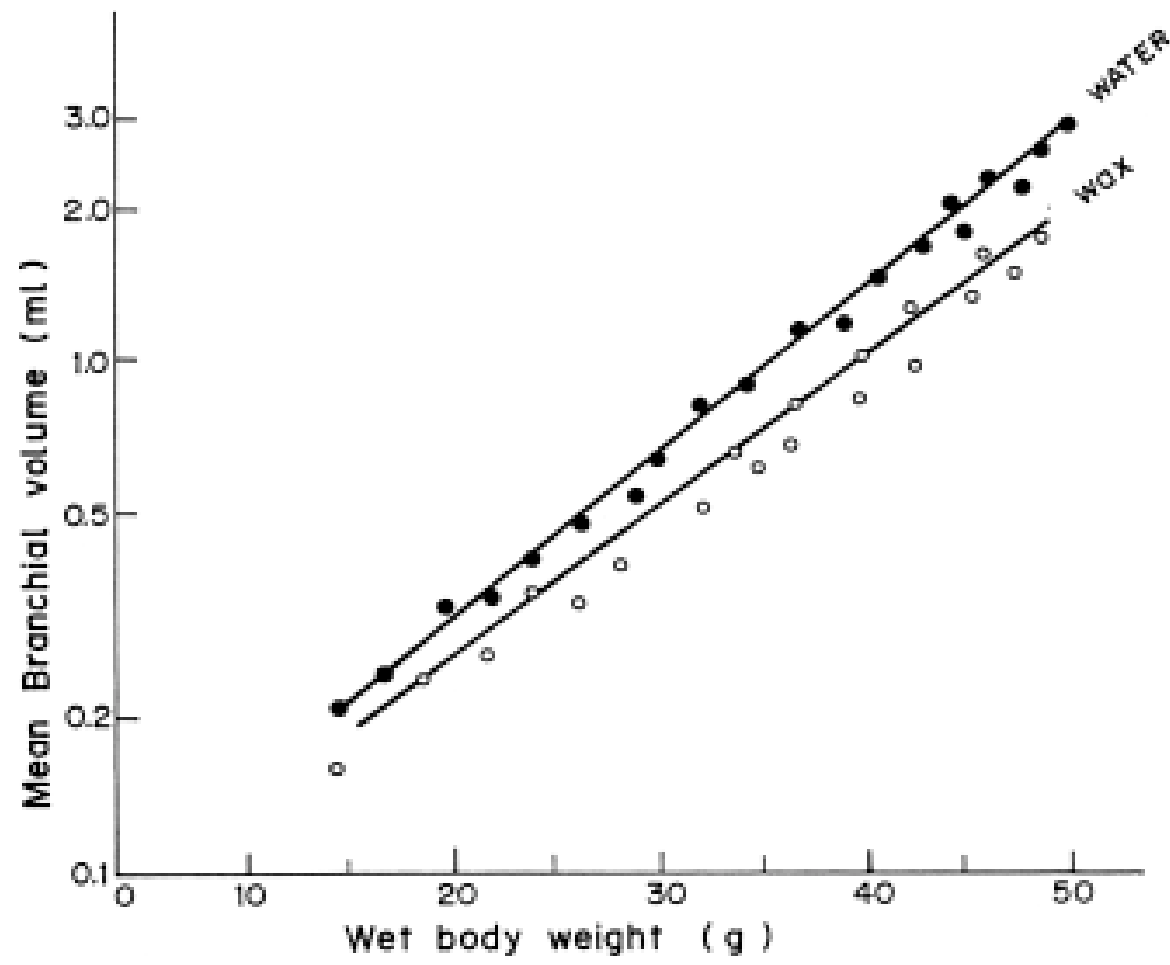

FIG. 5. Relationship between mean branchial chamber volume and wet body weight $(\mathrm{O})$ using water method (O) using paraffin wax method.

TABLE 7. Regression equations for mean branchial chamber volume by water and wax method against wet body weight.

\begin{tabular}{|c|c|c|c|}
\hline & Regression equation & $\mathrm{r}$ & $\mathrm{n}$ \\
\hline & $\log _{10} \mathrm{y}=\log _{10} \mathrm{a}-\mathrm{b} \log _{10} \mathrm{x}$ & & \\
\hline Water method & $\log _{10} \mathrm{y}=-3.07+1.99 \log _{10} \mathrm{x}$ & 0.99 & 20 \\
\hline Wax method & $\log _{10} \mathrm{y}=-3.1+1.90 \log _{10} \mathrm{x}$ & 0.88 & 20 \\
\hline
\end{tabular}

In each case the regression line is a highly significant fit $(\mathrm{p}<0.001)$. 


\section{Discussion}

The rate of weight specific oxygen consumption in Grapsus tenuicrustatus was consistently lower in water compared to the rate in air. Taylor and Davis (1982) and Eshky et al. (1988) found exactly the same relationship in Gecarcinus lateralis and Ocypode saratan respectively. During immersion in sea water Grapsus tenuicrustatus appeared to be stressed and displayed continuous pumping and an elevated pumping rate (Eshky, 1992). A similar stress was observed in the semi-terrestrial crab Ocypode saratan (Eshky et al., 1990). Taylor and Davies (1981) reported similar stress also in the land crab Gecarcinus lateralis. They interpreted this stress as being due to the respiratory system failing to deliver sufficient oxygen to meet the demands of the tissues.

A dramatic increase in scaphognathite pumping rate associated with submergence of Grapsus tenuicrustatus and a similar case with Oxypode saratan was also reported by Eshky (1992b) and Eshky et al. (1988) respectively. This response is similar to that seen during hypoxia in marine decapods since, for semi-terrestrial adapted crabs, water is essentially hypoxic medium. During laboratory observations for three days, Grapsus tenuicrustatus never submerged itself in the water, and during visits to the water, only half of the body was immersed on the water edge. Pearse (1929) showed that Ocypode quadrata died following prolonged submersion. The same was true of Gecarcinus lateralis (A.A. Taylor unpublished observations). Gross (1964) indicated that Ocypode quadrata can only withstand short periods of immersion.

The aerial oxygen consumption and heart beat rates of Grapsus tenuicrustatus were consistently higher in small crabs than in large crabs over the whole range of experimental temperatures investigated. The data presented show that Grapsus tenuicrustatus is well adapted to survive in a fluctuating, high temperature environment. The $\mathrm{Q}_{10}$ data for both oxygen consumption and heart rate were consistent between 20 and $30^{\circ} \mathrm{C}$, particularly between 20 and $30^{\circ} \mathrm{C} . \mathrm{Q}_{10}$ values for heart rate were higher than those for the oxygen consumption. This suggests that there must be either compensatory changes in the blood oxygen delivery or changes in the stroke volume of the heart. At present this cannot be decided without further investigation. Similar results were reported (Eshky, 1985) for the ghost crab Ocypode saratan.

It is now well established that in many invertebrates which experience a wide range of environmental temperature, the metabolic rates of quiescent animals show a degree of temperature independence $\left(\mathrm{Q}_{10}<2\right)$ (Newell, 1979). This has also been confirmed in a number of decapod crustaceans (McFarland Pickens, 1965; Burggren and McMahon, 1981; Morris and Taylor, 1985; and Eshky et al., 1988). There is little information, however, on $\mathrm{Q}_{10}$ values in suprallitoral decapods. Burggren and McMahon (1981) demonstrated higher values (2.6-2.7) for the supralittoral hermit crabs whereas in littoral species $\mathrm{Q}_{10}$ value was less than 2. Eshky (1988) demonstrated $\mathrm{Q}_{10}$ value for Ocypode saratan lower than those obtained by Burggren and McMahon (1981).

The present study on Grapsus tenuicrustatus indicates lower $\mathrm{Q}_{10}$ values than those obtained by Eshky et al. (1988) for Ocypode saratan. This clearly indicates that the supralittoral Grapsus tenuicrustatus is less adapted for terrestrial life than the two supralit- 
toral hermit crabs reported by Burggren and McMahon (1981) and the semi-terrestrial ocypode saratan (Eshky et al., 1988). Within the normal environmental temperature range $\left(20-30^{\circ} \mathrm{C}\right) \mathrm{Q}_{10}$ values for heart rate and oxygen consumption were consistently less than 2 , though they were closer to 2 and occasionally slightly higher than 2 . The behavioral differences of littoral and supralittoral animals influence the rate of change of body temperature as, for example, in the hermit crabs which occupy shells that influence the $\mathrm{Q}_{10}$ values of Grapsus tenuicrustatus. Due to this behavioral adaptation, the crab takes advantage of deep crevices and in its rocky habitat as well as adjacent splash zone and rock pool to control temperature.

There is no comparative information available for respiration in Grapsus species. Some data exist for other semi-terrestrial crabs such as the members of the tropical and sub-tropical family Ocypodea, as, for example, some data exist for Ocypode quadrata and Oxypode saratan. Yet, there is a wide variation in reported aerial rates of oxygen consumption in quiescent crabs. Wolcott (1978) studied Ocypode quadrata from North Carolina. His data for metabolic rate as a function of body size were described by the equation $(\log \mathrm{y}=0.69 \log \mathrm{x}+2.16)$ where $\mathrm{x}=$ wet weight $(\mathrm{g})$ and $\mathrm{y}=\mu \mathrm{lo}_{2} / \mathrm{g} / \mathrm{h}$. The equivalent equation from the work of Innes and Taylor (1986) on Ocypode quadrata from Trinidad is $\log \mathrm{y}=0.59 \log \mathrm{y}+2.07$. In the present work on Grapsus tenuicrustatus the mean crab weight for the $25^{\circ} \mathrm{C}$ data was $25 \mathrm{~g}$, and had an oxygen consumption rate of $67.4 \mu \mathrm{lo}_{2} / \mathrm{g} / \mathrm{h}$. Employing Wolcott's formula in its weight specific form, a specimen of Ocypode quadrata of $29 \mathrm{~g}$ weight has an aerial oxygen consumption rate of 51 $\mu \mathrm{lo}_{2} / \mathrm{g} / \mathrm{h}$ whereas the equivalent calculation from the data of Innes and Taylor (1986) gives an oxygen consumption rate of $30 \mu \mathrm{lo}_{2} / \mathrm{g} / \mathrm{h}$.

The equation from the work of Eshky et al. (1988) on Ocypode saratan was log $\mathrm{y}=$ 2.874-0.61 $\log \mathrm{x}$ where all sets of data were obtained at $25^{\circ} \mathrm{C}$. Applying the latter equation gives 105 equivalent only $30 \mu \mathrm{lo}_{2} / \mathrm{g} / \mathrm{h}$. The difference in the slopes of the regression equations between the present study and previous study means that differences in respiratory rate are more pronounced in small animals than large ones. There is much variation in the value of $b$ (slope) in the equation $V O_{2}=a w^{b-1}$ whereas $V O_{2}$ is the weight specific rate of oxygen consumption, $a=$ constant denoting the intercept of the regression line on the $y$-axis and $w=$ the body weight. The marked differences in $\mathrm{VO}_{2}$ values for different decapode species are unclear and may reflect differences in experimental technique and/or in the size ranges of animal sizes tested (Bridges and Brand, 1980).

It has been reported by several studies that the total gill area per gram body weight of brachyuran crabs decreases with increasing terrestriality. The data of Gray (1957) are widely quoted in supported of this hypothesis. The present study also supports this hypothesis for Grapsus tenuicrustatus as the rate of weight oxygen consumption was consistently lower in water compared to the rate in air. Also Eshky et al. (1988) has shown that a reduction in aquatic respiration for the semi-terrestrial crab Ocypode saratan and the mangrove crab Uca inversa and Metapograpsus messor respectively (Table 8). 
TABLE 8. Gill area and aquatic and air respiration of active semi-terrestrial brachyuran crabs.

\begin{tabular}{|c|c|c|c|c|c|}
\hline Species & $\begin{array}{l}\text { Live } \\
\text { weight } \\
\text { (g) }\end{array}$ & $\begin{array}{l}\text { Gill area } \\
\left(\mathrm{mm}^{2} \mathrm{~g}^{-1}\right)\end{array}$ & $\begin{array}{c}\text { Aquatic } \\
\text { respiration } \\
\left(\mu \mathrm{lo}_{2} \mathrm{~g}^{-1} \mathrm{~h}^{-}\right)\end{array}$ & $\begin{array}{c}\text { Air } \\
\text { respiration } \\
\left(\mu \mathrm{lo}_{2} \mathrm{~g}^{-1} \mathrm{~h}^{-}\right)\end{array}$ & Authors \\
\hline \multicolumn{6}{|l|}{ Family: } \\
\hline \multicolumn{6}{|l|}{ Ocypodidae } \\
\hline \multirow[t]{3}{*}{ Ocypode albicans } & 11.2 & 446 & - & $138 *$ & Gray (1957) \\
\hline & 45.8 & 325 & - & $76^{*}$ & \\
\hline & 77.3 & 194 & - & - & \\
\hline \multirow[t]{2}{*}{ O. platytarsis } & 5 & 280 & 138 & 160 & Veerannan (1974) \\
\hline & 8 & 225 & 120 & 125 & \\
\hline \multirow[t]{2}{*}{ O. saratan } & 11.6 & 454 & 92 & 198 & Eshky (1985) \\
\hline & 42.6 & 355 & 49 & 93 & \\
\hline \multicolumn{6}{|l|}{ Family: } \\
\hline \multicolumn{6}{|l|}{ Grapsidae } \\
\hline Sesarama cinerea & 1.5 & 638 & - & 132 & Gray (1957) \\
\hline Meteopograpsus Messor & - & - & - & & \\
\hline \multirow[t]{2}{*}{ Grapsus tenuicrustatus } & 11.6 & 595 & 94.5 & 169.8 & Present work \\
\hline & 42.6 & 377 & 40.7 & 85.8 & \\
\hline
\end{tabular}

*Pearse (1929) quoted and corrected from Gray (1957).

Similarly, as shown above, the aerial respiration for Grapsus tenuicrustatus is more efficient than aquatic respiration. With submerged crabs responding as though water was hypoxic medium. McMahon and Wilkens (1983) have reported similar results for terrestrial and semi-terrestrial species. Eshky (1985) and Bridges et al. (1997) have reported that the blood of semi-terrestrial ocypode saratan and Ocypode quadrata is characterized by having a higher oxygen affinity than that of most aquatic species. Also by judging the mechanism for drawing the water and the airflow inside the branchial chambers for Grapsus tenuicrustatus (Eshky, 1992a\&b). All these evidences in the present investigation, and other related literatures showed that Grapsus tenuicrustatus is well adapted for a semi-terrestrial environment.

Acknowledgement: The author wants to thank Dr. A. Al-Hasan for his support and assistance. The help of Dr. A. Grandi and Mr. M. Siad in the acquisition and maintenance of the crabs is greatly acknowledged. Also I highly appreciate Mr. A. Oden for his help in setting up electronic equipment. Many thanks are also due to Dr. S. Raheem Al-Deen for his assistance in processing some statistical aspects.

\section{References}

Alexander, S.J. and Ewer, D.W. (1969) A Comparative study of some aspects of biology of Sesarma catenata Ort. and Cyclograpsus punctatus M. Edw., with additional observations on Sesarma meinerti De Man. Zool. Africana 4: 1-35.

Al-Wassia, A.H., Innes, A.J., Taylor, E.W. and Whiteley, N.M. (1988) Aerial and aquatic respiratory gas exchange in the ghost crab Ocypode saratan. J. Physiol. 403: 106. 
Ayers, J.C. (1938) Relationship of habitat to oxygen consumption by certain estuarine crab. Ecology 19: 523527.

Banerjee, S.K. (1960) Biological results of the Snellius Expedition. XVIII. The genera Grapsus, Geograpsus and Metropograpsus (Crustacea Branchyura). Temnickia 10: 132-139.

Barnard, K.H. (1950) Descriptive catalogue of South African decapod Crustacea. Ann. S. Afr. Mus. 38: 1837.

Bridges, C.R. and Brand, A.R. (1980) Oxygen consumption and oxygen independence in marine crustaceans. Mar. Ecol. Prog. Ser. 2: 133-141.

, Humpperts, V., Eshky, A.A. and Taylor, A.C. (1977) Hamocyanin transport in Ocypode spp. modulation of oxygen affinity. J. Mar. Biol. Ass. UK, 77: 145-158.

Burggren, W.W. and McMahon, B.R. (1981) Oxygen uptake during environmental temperature changes in hermit crabs: adaptation to subtidal intertidal and supratidal habitats. Physol. Zool. 54: 325-333.

Burtnett, L.E. (1988) Physiological response to air exposure: acid-base balance and the role of branchial water stores. American Zoologist 28: 53-64.

Crosnier, A. (1965) Crustaces Decapodes Grapsidae et Ocypodidae. Fauna de Madagascar. 18: 1-143.

Davies, P.S. (1966) A constant pressure respirometer for medium-sized animals. Oikos 17: 108-112.

DeFur, P.L. (1988) Systematic respiratory adaptations to air exposure in intertidal decapod crustacea. American Zoologist. 28: 11-24.

Diaz, H. and Rodrigues, G. (1977) The branchial chamber in terrestrial crabs. Comparative study. Biol. Bull. Woods Hole 153: 185-504.

Eshky, A.A. (1980) Systematics and zoogeography of some brachyuran crabs of Eastern Coast of the Red Sea. MSc. Thesis, Whittier College, California: $164 \mathrm{p}$. (1985) Aspects of the ecology behavior and physiology of the ghost crab Ocypode saratan (Forskal). Ph.D. Thesis. University of Glasgow: $250 \mathrm{p}$.

- (1992a) Evidence of additional functions of the pericardial sacs in the branchial ventilation in the Grapsid crab Grapsus tenuicrustatus. JKAU Mar. Sci. 3: 91-104.

(1992b) Behavioural ecology and heat responses of the mangrove crabs (Uca-spp) at Madia Creek near Jizan city. JKAU Mar. Sci. 3: 67-79.

—, Atkinson, R.J.A. and Taylor, A.C. (1988) Effects of temperature on oxygen consumption and heart rate in the semi-terrestrial crab Ocypode saratan (Forskal). Mar. Behav. Physiol. 13: 341-358.

—, El-Wassia, A.H., Atkinson, R.J.A. and Taylor, C.A. (1990) Branchial ventilation in the Ghost Crab Ocypode Saratan. Mar. Behav. Physiol. 16: 237-248.

Forest, J. and Guinot, D. (1961) Crustaces Decapodes Brachyoures de Tahiti et des Taumoto In: Expedition Francaise sur les Recifs Coralliens Dela Nouvellecaledonie Volume Preliminaire. Editions de la Fondation Singer-Polignac Paris: 1-195.

Foster, M.e., Waldron, F.M. and Taylor, H.H. (1989) Recovery from exhausting exercise in a bimodally breathing crab Leptograpsus variegatus (Decapode: Grapsidae). J. Exp. Mar. Biol. Ecol. 127: 165-73.

Gray, I.E. (1957) A comparative study of gill area of crabs. Biol. Bull. Wood Hole, 112: 34-42.

Greenaway, P., Morris, S., Sanders, S. and Adamczewka, A. (1992) Blood Gas Transport and Oxygen Consumption in a Sublittoral Crab, Leptograpsus variegatus. (Crustacea: Brachyura). Aust. J. Mar. Freshwater Res. 43: 1573-84.

and Taylor, H.H. (1976) Aerial gas exchange in the Australian arid-zone crab Parathelphusa transversa (Von Martins). Nature (London), 262: 711-713.

Gross, W.J. (1964) Trends in water and salt regulation among aquatic and amphibious crabs. Biol. Bull. Mar. Biol. Lab. Woods Hole 127: 447-446.

Hawkins, A.J.S. and Jones, M.B. (1982) Gill area and ventilation in two mud crabs, Helice crassa Dona (Grapsidae) and Macrophathalmus hirtipes (Jacquinot) (Ocypodidae) in relation to habitat. J. Exp. Mar. Biol. Ecol. 60: 103-118.

Hoggarth, K.R. and Trueman, E.R. (1967) Techniques for recording the activity of the aquatic invertebrates. Nature (London) 213: 1050-1051.

Innes, A.J. and Taylor, E.W. (1986) Air breathing crabs of Trinidad: adaptive radiation into terrestrial environment -1 aerobic metabolism and habitat. Comp. Biochem. Physiol. 85A: 373-381.

Lucu, C. and Pavicic, D. (1995) Role of seawater concentration and major ions in oxygen consumption rate 
of isolated gills of the shore crab Carcinus mediterraneus. Comp. Biochem. Physiol. 112A, No. 3-4: 565-572.

McFarland, W.N. and Pickens, P.E. (1965) The effects of season temperature and salinity on standard and active oxygen consumption in the grass shrimp Palaemonetes vulgaris. Can. J. Zool. 43: 571-585.

McMahon, B.R. (1988) Physiological responses to oxygen depletion in intertidal animals. American Zoologist. 28: 39-53.

- and Burggren, W.W. (1988) Respiration. In 'Biology of the Land Crabs'. (Eds W.W. Burggren and B.R. McMahon). 249-97, Cambridge University Press.

- and Wilkens, J.L. (1983) Ventilation perfusion and oxygen uptake. In: Mantell, L.H. (ed) Bliss, D.E. (ed-in-chief). The Biology of Crustacea Internal Anatomy and Physiological Regulation. Academic Press, New York 5: 289-372.

Morris, S. and Taylor, A.C. (1985) Oxygen consumption by palaemon elegans (Rathke) in response to temperature change: a determinant of distribution. Exp. Biol. 44: 255-268.

Newell, R.C. (1979) Biology of Intertidal Animals. 3rd edition, Marine Ecological Surveys Ltd Faversham: 781.

Pearse, A.S. (1929) Observations on certain littoral and terrestrial animals at Tortugas Florida with special reference to migrations from marine to terrestrial habitats. Pap. Tortugas Lab. Carnegie Inst. Washington 39: 205-223.

Taylor, A.C. and Davies, P.S. (1981) Respiration in the land crab Gecarcinus lateralis. J. Exp. Biol. 93: 197208.

and Davies, P.S. (1982) Aquatic respiration in the land crab, Gecarcinus lateralis (Freminville). Comp. Biochem. Physiol. 72A: 683-688.

Veerannan, K.M. (1974) Respiratory metabolism of crabs from marine and estuarine habitats: an interspecific comparison. Mar. Biol. 26: 35-43.

Vernberg, F.J. (1956) Study on the oxygen consumption of excised tissue of certain marine decapod Crustacea in relation to habitat. Physiol. Zool. 29: 227-341.

Wolcott, T.G. (1978) Ecological role of ghost crabs Ocypode quadrata (Fabricius) on an ocean beach: scavengers or predators. J. Exp. Mar. Biol. Ecol. 31: 67-82. 


\section{التأقلم الفسيولوجي لسرطان الصخور البرمائي جرابسس

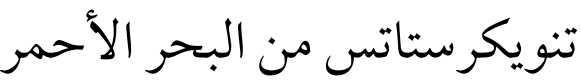

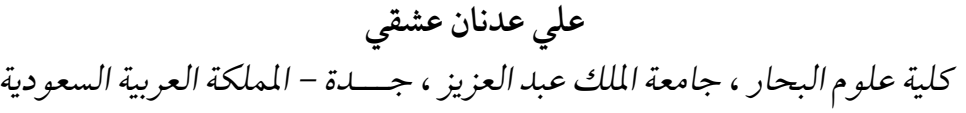

المستخلص · تضمنت هذه الدراسة دراسة التأقلمات الفسيولوجية

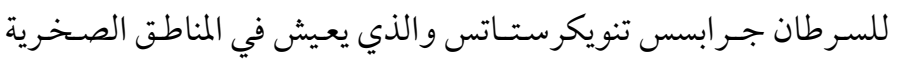

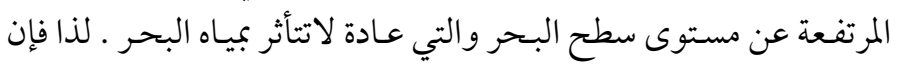

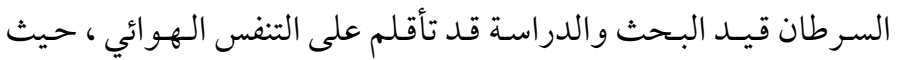

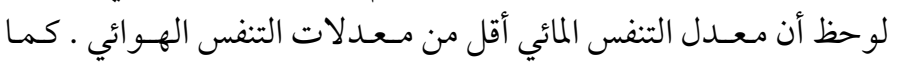

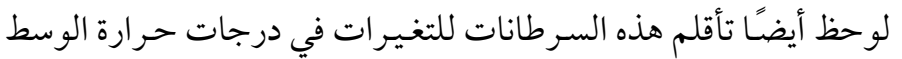

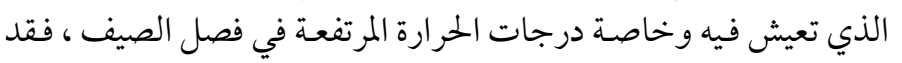

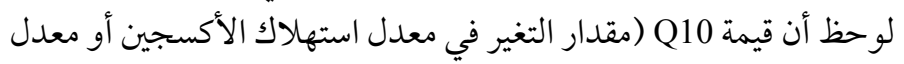

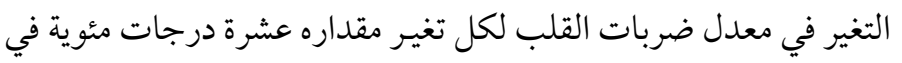

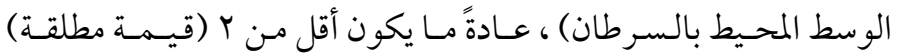

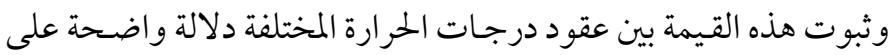

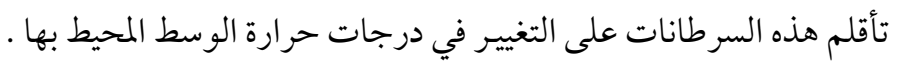

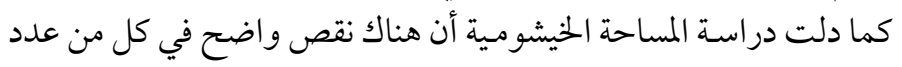

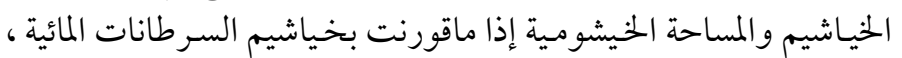

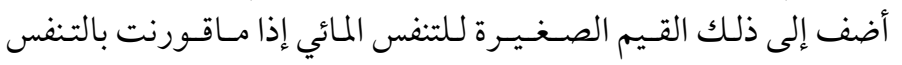

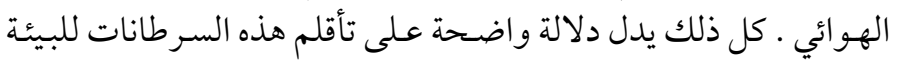

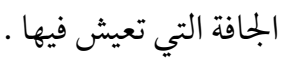

